Publisher homepage: www.universepg.com, ISSN: 2707-4668 (Online) \& 2707-465X (Print)

https://doi.org/10.34104/ajssls.021.085088

Asian Journal of Social Sciences and Legal Studies

Journal homepage: www.universepg.com/journal/ajssls

\title{
Forced labor and the legal issues: In the context of Bangladesh
}

\section{Ibtida Farhat Tropa*}

Department of Law, Faculty of Law, Eastern University, Dhaka-1345, Bangladesh.

*Correspondence: ibtidatropa@ gmail.com (Ibtida Farhat Tropa, Senior Associate, A. S \& Associates, Dhaka, Bangladesh).

\begin{abstract}
Modern slavery is currently the most talked about topic in the world. One of the most common forms of modern slavery is forced labor, which is very common in underdeveloped countries like the countries in South Asia. Forced labor means any work which is done by the worker without his willingness but the worker is bound to do the work due to the circumstances like poverty, the threat of life or property, etc. Therefore, mostly the countries which are fighting for survival like Bangladesh are mostly affected by this problem. However, in Bangladesh, forced labor is a punishable offense and also prohibited by the Constitution of the Peoples' Republic of Bangladesh. Accordingly, Bangladesh has enacted an Act to prohibit forced labor. But due to the economic struggle, unstable political situation, and other issues the country is failing to prevent the offense. The only collective attempt may prevent forced labor from the country.
\end{abstract}

Keywords: Modern slavery, forced labor, compulsory labor, involuntary employment, and commercial gain.

\section{INTRODUCTION:}

Indeed, it seems like the modern era is free from the aggression of slavery and all people of this world are living in this world with similar happiness and selfsatisfaction with respect. No, the notion is completely incorrect; slavery still very much exists in a mutated form. Many of us find it difficult to accept that modern slavery is more common than at any other point in history. Countries all over the world face similar difficulties in efficiently controlling labor. These include casual work in various forms. Recent developments in the wrong direction include restricting migrants' rights, prioritizing the rights of businesses over their workers (Al-Amin et al, 2020). Since modern slavery is so prevalent, it's impossible that any company's activities or supply chains are free of it. If we flashback on ourselves and look into the slavery period, what will we find? We will figure out UniversePG I www.universepg.com that people were kidnapped from the continent of Africa, forced into slavery in American colonies and exploited to work as indentured servants and labor in the production of the crops, in consideration of nothing.

Fast-forward to today's date, not much contrasting picture is seen particularly in the countries like Bangladesh and other South Asian countries which are striving with the poverty, illiteracy, etc (Arifuzzaman et al., 2021). Due to the poverty, even now children in this continent are forced to work instead of continuing their education, women are coerced into activities like prostitution or almost anything that they are not obliged to do but are compelled on doing owing to their circumstances. If looked into it, there are numerous cases of forced labor that can be found. As a result, the darkness of slavery continues to exist over 
the world. Modern slavery has no specific definition; however, it can be defined as the extreme exploitation of one individual for personal and/or commercial gain. One of the most common components of modern slavery is forced labor and/or bonded labor which the majority of the developing countries are dealing with. More often than not, forced labor refers to any compelled employment of those who are threatened somehow or other. People are compelled to work by the threat or use of abuse, as well as physical, mental, or financial constraints. Bonded labor, also known as debt slavery, is a common practice in which people are forced to work in order to repay a debt.

In the regulatory holes of global supply chains, these activities flourish. They're common in India textiles, Thai fishing, and Chinese manufacturing, for example. In the case of Saladin v France, (2005), a 15-year-old girl who was brought from Togo to France by person 1, who paid for her travel but then, took her passport. The girl was made to work for person -1 till she paid off her flight ticket, but after a few months, she was 'loaned' to some other couple where she was compelled to work without any day off, 15 hours a day without any authorization of her immigrant status. It was ruled by the European Court of Human Rights that the girl had been kept in serfdom. There are countless instances of forced labor in Bangladesh.

Excessive charges for charges of transport, tools, food, accommodation and interest on existing loans, paying salary below that the minimum wages and in kind, withholding work for a period of time, contract substitution, non-payment, under payment or deferred payment of wages, illegal deductions of wages all these are considered as the forced labor. Because of the financial position, the overwhelming majority of people in our country are compelled to work against their will. Under the prevailing laws of Bangladesh, forced labor is punishable offence. As per section 2(4) of "The Prevention and Suppression of Human Trafficking Act (PSHT), 2012, (the "Act")" forced labor means if any person forced to do any work under the threat of the damage of his life, independence, rights, assets or goodwill is forced labor. International Labor Organization Forced Labor Convention, (1930), (No. 29), also defined the term forced labor. As per the definition of the Convention it appears that Forced or compulsory labor is any task or service that is demanded of a person under threat of punishment and for which the person has not voluntarily given himself or herself.

Forced labors are mostly applied in the informal sectors like as:

- Agricultural and fishing;

- Domestic and/or household Work;

- Construction, mining and brick kilns;

- Manufacturing, processing and packaging;

- Prostitution, brothel and sexual exploitation;

- Begging or any other illegal activities (ITUC Guide, 2009).

Article 34 of the Constitution of the Peoples' Republic of Bangladesh prohibits forced labor and it also referred forced labor as a punishable offence. However, it is pertinent to mention here that the Constitution mentioned certain exceptional grounds, which shall not be considered as the forced labor. The grounds are as following:

- The person undergoing lawful punishment for a criminal offence; and

- Any work for the purpose of public interest.

Also, it should not be out of place to mention here that International Labor Organization Forced Labor Convention, 1930 (No. 29), also referred following grounds which shall not be considered as the forced labor:

0 any work or service exacted in virtue of compulsory military service laws for work of a purely military character.

0 any work or service which forms part of the normal civic obligations of the citizens of a fully self-governing country.

$\circ$ any work or service exacted from any person as a consequence of a conviction in a court of law, provided that the said work or service is carried out under the supervision and control of a public authority and that the said person is not hired to or placed at the disposal of private individuals, companies or associations.

- any work or service exacted in cases of emergency, that is to say, in the event of war or of a 
calamity or threatened calamity, such as fire, flood, famine, earthquake, violent epidemic or epizootic diseases, invasion by animal, insect or vegetable pests, and in general any circumstance that would endanger the existence or the wellbeing of the whole or part of the population.

- minor communal services of a kind which, being performed by the members of the community in the direct interest of the said community, can therefore be considered as normal civic obligations incumbent upon the members of the community, provided that the members of the community or their direct representatives shall have the right to be consulted in regard to the need for such services (International Labor Organization Forced Labor Convention, ILOFLC, 1930).

Apart from the aforementioned grounds, all other forms of forced labor shall be deemed a penal offense as directed by Bangladesh's Constitution and regulated by law. Forced labor, bonded labor, human trafficking, kidnapping, sexual exploitation without consent, and confinement in a brothel are all interconnected. And for these kinds of infractions, the Act imposed sanction in a strictly manner. A brief chart of punishment as per the Act given as below table:

\begin{tabular}{|c|c|c|c|c|c|c|}
\hline \multirow[t]{2}{*}{ Name of the Offence } & \multirow{2}{*}{$\begin{array}{l}\text { Relevant } \\
\text { Section }\end{array}$} & \multicolumn{3}{|c|}{ Imprisonment } & \multirow{2}{*}{$\begin{array}{c}\text { Fine } \\
\text { (In Taka) }\end{array}$} & \multirow{2}{*}{$\begin{array}{c}\text { Other } \\
\text { Punishment }\end{array}$} \\
\hline & & Minimum & Maximum & Type & & \\
\hline Human Trafficking & Section 6 & 5 years & Life imprisonment & Rigorous & $\begin{array}{l}\text { Minimum } \\
50,000.00\end{array}$ & $\begin{array}{c}\text { Not } \\
\text { Applicable }\end{array}$ \\
\hline $\begin{array}{l}\text { Organized Offence of } \\
\text { Human Trafficking }\end{array}$ & Section 7 & 7 years & $\begin{array}{l}\text { Death Penalty or } \\
\text { Life imprisonment }\end{array}$ & Rigorous & $\begin{array}{c}\text { Minimum } \\
500,000.00\end{array}$ & $\begin{array}{c}\text { Not } \\
\text { Applicable }\end{array}$ \\
\hline $\begin{array}{l}\text { Instigating, Conspiring, or } \\
\text { attempting to commit the } \\
\text { offence }\end{array}$ & Section 8 & 3 years & 7 years & Rigorous & $\begin{array}{l}\text { Minimum } \\
20,000.00\end{array}$ & $\begin{array}{c}\text { Not } \\
\text { Applicable }\end{array}$ \\
\hline $\begin{array}{c}\text { Forced or bonded labor or } \\
\text { service }\end{array}$ & Section 9 & 5 years & 12 years & Rigorous & $\begin{array}{l}\text { Minimum } \\
50,000.00\end{array}$ & $\begin{array}{c}\text { Not } \\
\text { Applicable }\end{array}$ \\
\hline \multirow[t]{2}{*}{$\begin{array}{l}\text { Kidnapping, stealing and } \\
\text { confining with the intent to } \\
\text { commit human trafficking }\end{array}$} & $\begin{array}{l}\text { Section } 10 \\
\text { (1) }\end{array}$ & 5 years & 10 years & Rigorous & $\begin{array}{l}\text { Minimum } \\
20,000.00\end{array}$ & $\begin{array}{c}\text { Not } \\
\text { Applicable }\end{array}$ \\
\hline & $10(2)$ & 5 years & Life imprisonment & Rigorous & $\begin{array}{l}\text { Minimum } \\
50,000.00\end{array}$ & $\begin{array}{c}\text { Not } \\
\text { Applicable }\end{array}$ \\
\hline $\begin{array}{l}\text { Importing or transferring } \\
\text { for prostitution or any } \\
\text { other form of sexual } \\
\text { exploitation or oppression }\end{array}$ & 11 & 5 years & 7 years & Rigorous & $\begin{array}{l}\text { Minimum } \\
50,000.00\end{array}$ & $\begin{array}{c}\text { Not } \\
\text { Applicable }\end{array}$ \\
\hline $\begin{array}{l}\text { Keeping brothel or } \\
\text { allowing any place to be } \\
\text { used as brothel }\end{array}$ & 12 & 3 years & 5 years & Rigorous & $\begin{array}{l}\text { Minimum } \\
50,000.00\end{array}$ & $\begin{array}{c}\text { Not } \\
\text { Applicable }\end{array}$ \\
\hline
\end{tabular}

Although there are applicable laws in the country to prevent such type of modern slavery yet how much the law is actually in implication? Can Bangladesh protect forced labor? The answer is "NO". Poverty, over population, unemployment, lack of awareness, bureaucratic system, corruption, unstable political condition all these are the contributing factors for forced labor. Raising public awareness is a good approach to remove forced labor. Public awareness can be raised by removing poverty, increase of the literacy rate, removing superstations, increase employment opportunities, combat discrimination in the workplace etc. So that people can learn and aware about their rights, need not to do any involuntary work due to financial reasons or crisis. Moreover, Trade Union of different sectors can play a vital role to eliminate forced labor from a country. There are several examples of positive role of trade union to remove forced labor from 
multiple countries. Accordingly, by the active movement of trade union United Kingdom amended its national legislation to stop forced labor from the nation, also Italian Labor union played key role to amend the Immigrations Act of the country, which provides 6 months' residency permit to the trafficked people in Italy, etc (ASO, 2021). Accordingly, the trade union can play a pivotal role to eradicate forced labor from a nation.

\section{CONCLUSION:}

At the same time, it should not be out of place to mention here that only raising public awareness cannot prevent any offence like forced lab our from Bangladesh. Besides raising public awareness, government intervention, cooperation of law enforcing authorities and the assistance of human rights ensuring organizations are highly required. This will necessitate some experimentation as well as the participation of those who are influenced by the rules. With the joint movement of all these only can erase forced lab our from Bangladesh.

\section{ACKNOWLEDGEMENT:}

This article is supported by one of the author's colleagues Ms. Afrin Sadia Nusrat, Research Associate of A.S \& Associates.

\section{CONFLICTS OF INTEREST:}

The author hereby declares that there is no conflict of interest in publication of this article.

\section{REFERENCES:}

1) Al-Amin M, Alam S, and Hossain S. (2020). Analysis of the present condition of garment workers' rights and its protection under domestic and international legal framework: Bangladesh perspective, Br. J. Arts Humanit., 2(6), 101-112. https://doi.org/10.34104/bjah.02001010112

2) Arifuzzaman M, Rafee FER, and Islam MJ. (2021). Exploration of poverty and human rights violation: a legal analysis, Asian J. Soc. Sci. Leg. Stud., 3(1), 10-22. https://doi.org/10.34104/ajssls.021.010022

3) ASO, (2021). New Plan for Immigration: impact on children needs to be mitigated "Anti-Slavery Organization, https://www.antislavery.org/new-plan-for-immi gration-children-ecpat/

4) Constitution of Peoples' Republic of Bangladesh, Article 23.

5) ILOFLC, (2030). International Labour Organization Forced Labour Convention, No 29, 1930.

6) ITUC, (2009). ITUC Guide: How to Combat Forced Labour and Trafficking, 2009.

https://www.ituc-csi.org/IMG/pdf/TU_Guide Forced labour_EN.pdf

7) PSHT, (2012). The Prevention and Suppression of Human Trafficking Act, 2012.

8) Siliadin v. France, (2005). European Court of Human Rights, July 26, 2005 , https://archive.crin.org/en/library/legaldatabase/siliadin-v-france.html

9) Sultana T. (2020). Labor demand and exportoriented industrialization of Bangladesh, Asian J. Soc. Sci. Leg. Stud., 2(6), 115-121. https://doi.org/10.34104/ajssls.020.01150121

Citation: Tropa IF. (2021). Forced labor and the legal issues: in the context of Bangladesh, Asian J. Soc. Sci. Leg. Stud., 3(3), 85-88. https://doi.org/10.34104/ajssls.021.085088 @ @ 